Jurnal Ilmu Sosial dan Pendidikan (JISIP)

Vol. 5 No. 3 Juli 2021

Terakreditasi Peringkat 5 (No. SK: 85/M/KPT/2020)

e-ISSN : 2656-6753, p-ISSN: 2598-9944

DOI: 10.36312/jisip.v5i3.2182/http://ejournal.mandalanursa.org/index.php/JISIP/index

\title{
Kemampuan Menulis Kreatif Puisi Siswa Kelas XI SMA Negeri 24 Watampone
}

\author{
Andi Srimularahmah ${ }^{1}$, A. Nurhabibi Marwil ${ }^{2}$ \\ STKIP MUHAMMADIYAH BONE \\ andisrimularahmah@gmail.com, nurnurnur399@gmail.com
}

\begin{tabular}{l}
\hline Article Info \\
Article history: \\
Article Accepted: 08 July 2021 \\
Publication : 15 July 2021 \\
\\
Keywords: \\
Kemampuan Menulis Kreatif \\
Puisi
\end{tabular}

Article Info

Article history:

Article Accepted: 08 July 2021

Publication : 15 July 2021

Keywords:

Kemampuan Menulis Kreatif Puisi

Corresponding Author:

Andi Srimularahmah

STKIP MUHAMMADIYAH BONE

Email: andisrimularahmah@gmail.com

\begin{abstract}
This study aims to describe the creative writing abilities of poetry students of class XI 24 Watampone High School on aspects, themes, mandate, tone, diction, language style, taste, concrete words and typography. This research is quantitative descriptive. The population of this study were all 28 students of class XI Watampone, totaling 288 students, divided into 9 classes. The sample set in the study as many as 32 people. Sampling is done with a purposive sample with the consideration that the subject under study has homogeneous properties and abilities. The technique used to collect data is a written ability test. That is, students are assigned to write poetry. The results showed that the ability to write poetry XI SMA Negeri 24 Watampone on aspects: themes, mandate, tone, diction, language style, feeling (feeling), concrete words and typography, were inadequate. This is caused by the results of the acquisition of the ability percentage of the eight indicators of poetry writing assessment not achieving the success criteria; that is, $85 \%$ score 7.0 and above.

Abstrak
Penelitian ini bertujuan mendeskripsikan kemampuan menulis kreatif puisi
siswa kelas XI SMA Negeri 24 Watampone pada aspek, tema, amanat, nada,
diksi, gaya bahasa, rasa (feeling), kata konkret dan tipografi. Penelitian ini
bersifat deskriptif kuantitatif. Populasi penelitian ini adalah semua siswa kelas
XI SMA Negeri 24 Watampone yang berjumlah 288 siswa terbagi dalam 9
kelas. Sampel yang ditetapkan dalam penelitian sebanyak 32 orang. Penarikan
sampel dilakukan dengan sampel purposif (purposive sample) dengan
pertimbangan bahwa subjek yang diteliti mempunyai sifat dan kemampuan
yang homogen. Teknik yang digunakan untuk mengumpulkan data adalah uji
kemampuan tertulis. Maksudnya, siswa ditugaskan menulis puisi. Hasil
penelitian menunjukkan bahwa kemampuan menulis kreatif puisi XI SMA
Negeri 24 Watampone pada aspek : tema, amanat, nada, diksi, gaya bahasa,
rasa (feeling), kata konkret dan tipografi, belum memadai. Hal ini disebabkan
oleh hasil perolehan persentase kemampuan dari delapan indikator penilaian
penulisan puisi tidak mencapai kriteria keberhasilan; yaitu $85 \%$ mendapat nilai
7,0 ke atas.
\end{abstract}

This is an open access article under the Lisensi Creative Commons AtribusiBerbagiSerupa 4.0 Internasional

\section{PENDAHULUAN \\ 1.1.Latar Belakang}

Kemampuan berbahasa adalah kemampuan menggunakan bahasa. Kemampuan itu terlihat di dalam empat aspek keterampilan. Keempat aspek itu adalah mendengarkan, berbicara, 
membaca, dan menulis. Kemampuan mendengarkan dan membaca disebut kemamampuan reseptif sedangkan kemampuan berbicara dan menulis dinamakan kemampuan produktif. Kemampuan reseptif dan kemampuan produktif dalam berbahasa merupakan dua sisi yang saling mendukung, saling mengisi, dan saling melengkapi. Seseorang yang ingin mengembangkan kemampuan berbicara dan menulis, mestilah banyak mendengar dan membaca. Oleh karena, dengan mendengar dan membaca akan diperoleh informasi untuk dibicarakan dan dituliskan. Mengembangkan kemampuan mendengar dan membaca, seyogyanya pula diawali dengan kegiatan berbicara dan menulis. Begitulah keempat aspek berbahasa itu saling mendukung.

Kemampuan menulis sebagai salah satu cara dari empat keterampilan berbahasa mempunyai peranan yang penting di dalam kehidupan manusia. Dengan menulis seseorang dapat mengungkapkan pikiran dan gagasan untuk mencapai maksud dan tujuannya. Seperti yang dikatakan oleh H.G. Tarigan, (1986:21), menulis adalah menurunkan atau melukiskan lambang-lambang grafik yang menggambarkan suatu bahasa yang dipahami oleh seseorang, sehingga orang lain dapat membaca lambang-lambang grafik tersebut. Dapat diartikan bahwa menulis adalah menempatkan simbol-simbol grafis yang menggambarkan suatu bahasa yang dimengerti oleh seseorang. Kemudian, lambang itu dapat dibaca orang lain yang memahami bahasa tersebut beserta simbol-simbol grafisnya.

Menulis adalah kegiatan melahirkan pikiran dan perasaan. Dapat juga diartikan bahwa menulis adalah komunikasi mengungkapkan pikiran, perasaan, dan kehendak kepada orang lain secara tertulis (Sumiamiharja, dalam Tarigan, 1986). Keterampilan menulis adalah kemampuan seseorang dalam melukiskan lambang grafis yang dimengerti oleh penulis bahasa itu sendiri maupun orang lain yang mempunyai kesamaan pengertian terhadap simbol-simbol bahasa.

Dalam menulis diperlukan adanya urutan logis dengan menggunakan kosa kata dan tata bahasa tertentu atau kaidah bahasa yang digunakan sehingga dapat menggambarkan atau dapat menyajikan informasi yang diekspresikan secara jelas. Itulah sebabnya untuk terampil menulis diperlukan latihan dan praktek terus menerus dan teratur.

Untuk menjadi seorang penulis yang baik, haruslah memiliki kepekaan terhadap keadaan sekitarnya agar tujuan penulisannya dapat dipahami oleh pembaca. Untuk menjadi seorang penulis yang terampil, penulis harus menentukan maksud dan tujuan penulisannya agar pembaca memahami ke arah mana tujuan penulisan. Kemudian harus dilihat juga kondisi pembaca artinya tulisan ini ditujukan kepada pembaca yang bagaimana (dalam hal usia, pengetahuan, minat). Faktor lain yang harus diperhatikan adalah waktu dan kesempatan, artinya apakah tulisan yang dibuat sesuai dengan berlangsungnya suatu kejadian sehingga menarik untuk dibaca.

Menulis kreatif puisi merupakan salah satu keterampilan dalam bidang apresiasi sastra yang harus dikuasai oleh siswa. Akan tetapi, pada kenyataannya pembelajaran menulis kreatif puisi di SMA Negeri 24 Watampone masih banyak kendala. Realita yang terjadi sekarang adalah siswa belajar sastra hanya karena tujuan mendesak, yakni memenuhi tuntunan kurikulum dan agar dapat lulus pada ujian akhir di tingkat SMA. Dampaknya, pelajaran sastra tidak dipahami dengan benar, siswa juga tidak menghargai dan menikmati nilai-nilai estetis yang terkandung dalam karya sastra, termasuk pembelajaran puisi. Hal ini disebabkan dalam pembelajaran puisi mereka saat berada di bangku sekolah sarat dibekali teori tentang puisi. Akhirnya, ketika siswa diminta menulis puisi, penuangan gagasan, dan perasaan tidak dapat diekspresikan dengan baik. Belajar yang diciptakan guru di dalam kelas hanya sebatas memberikan informasi pengetahuan tentang sastra sehingga kemampuan mengapresiasi dan kemampuan mencipta kurang mendapat perhatian yang terjadi pada proses transfer pengetahuan tentang sastra dari guru kepada siswa.

Siswa kurang mendapat kesempatan untuk melakukan konstruksi pengetahuan dan melakukan pengembangan pengetahuan itu menjadi sebuah produk pengetahuan baru. Oleh karena itu, pihak yang terlibat dalam pendidikan formal harus meramu sedemikian rupa sistem pendidikan dan pembelajaran sastra agar dapat memberikan rangsangan kognitif, efektif, dan 
psikomotor pada diri anak didik. Dengan demikian, pembelajaran sastra termasuk pembelajaran puisi bukan hanya berorientasi untuk memberikan pengetahuan tentang sastra, melainkan dapat memupuk daya apresiasi dan daya cipta anak.

Berdasarkan uraian tersebut, dalam kemampuan menulis khususnya menulis kreatif puisi perlu diteliti. Oleh karena itu, peneliti tertarik untuk mengetahui lebih jauh kemampuan siswa dalam menulis kreatif puisi dengan judul "Kemampuan Menulis Kreatif Puisi Siswa Kelas XI SMA Negeri 24 Watampone"

\subsection{Rumusan Masalah}

Berdasarkan latar belakang yang telah diuraikan, maka rumusan masalah dalam penelitian ini adalah: Bagaimanakah kemampuan menulis kreatif puisi siswa kelas XI SMA Negeri 24 Watampone?

\subsection{Penelitian Relevan}

Beberapa hasil penelitian sastra menunjukkan bahwa kondisi pembelajaran sastra masih kurang memuaskan seperti : hasil penelitian Suhartini (2004) yang berjudul "Kemampuan Menulis Puisi Siswa Kelas III Bahasa SMA Negeri 1 Bajeng", menyatakan bahwa kemampuan siswa kelas 3 bahasa SMAN 1 Bajeng dalam menulis puisi belum memadai. Begitu pula hasil penelitian yang dilakukan oleh Zaida (2006) yang berjudul "Kemampuan Menulis Kreatif Jenis Puisi Siswa Kelas VII SMP 3 Makassar", menyatakan bahwa kemampuan siswa kelas VII SMP 3 Makassar dalam menulis kreatif puisi belum memadai. Penetian tindakan kelas dilakukan oleh Wijayanti, Ervina. 2013. "Peningkatan Kemampuan Menulis Puisi dengan Menggunakan Media Gambar Seri Siswa Kelas VIII SMP Negeri 2 Piyungan Bantul Tahun Ajaran 2011/2012"mengalami peningkatan yang lebih baik dari sebelumnya dalam menulis kreatif puisi.

\section{LANDASAN TEORI}

\subsection{Menulis Kreatif}

Pada hakikatnya, menulis adalah pengutaraan sesuatu dengan menggunakan bahasa secara tertulis (Karsana, 2002: 5). Mengutarakan sesuatu itu dimaksudkan menyampaikan, memberitakan, menceritakan, melukiskan, menerangkan, meyakinkan, menjelmakan, dan sebagainya kepada pembaca agar memahami apa yang terjadi pada peristiwa atau suatu kegiatan. Cere (dalam Mills, 2011) menyatakan menulis merupakan komunikasi. Selanjutnya dikatakan bahwa di dalam komunikasi terdapat empat unsur, yaitu menulis merupakan (1) bentuk ekspresi diri; (2) sesuatu yang umum disampaikan ke pembaca; (3) aturan dan tingkah laku; serta (4) menulis merupakan sebuah cara belajar.

Sebagai bentuk dari ekspresi diri, menulis bertujuan untuk mengkomunikasikan, menyampaikan sebuah ide melewati batas waktu dan ruang. Artinya, menulis dapat dilakukan kapan saja, dan di mana saja sesuai dengan keadaan yang terdapat dalam diri penulis. Avelrod dan Cooper (dalam Mills, 2011) menyatakan bahwa menulis merupakan suatu proses penemuan yang kompleks dan membuat seseorang dapat belajar mengatur waktu. Menulis merupakan sebuah refleksi dalam diri seseorang yang tumbuh melalui suatu proses. Seseorang yang dapat menulis dengan baik, tentunya telah melalui berbagai latihan yang terus menerus. Dengan latihan secara berkesinambungan ditambah dengan adanya kegemaran seseorang terhadap menulis akan berimplikasi kepada hasil menulisnya. Tarigan (1986:21) yang menyitir pendapat Lado mengemukakan bahwa menulis adalah menuliskan lambang-lambang grafik yang menggambarkan suatu bahasa yang dipahami oleh seseorang sehingga orang lain dapat membaca lambang-lambang grafik tersebut kalau memahami bahasa dan grafik tersebut.

Akhadiah (dalam Wicaksono 2014) mengemukakan bahwa menulis merupakan kemampuan kompleks yang menuntut sejumlah pengeta-huan dan keterampilan. Jadi, dapat dijelaskan bahwa dalam mencapai taraf mampu menulis diperlukan berbagai syarat yang mendukung. Kegiatan menulis membutuhkan suatu kemampuan yang cermat dan terintegrasi dalam mengorganisasikan tulisan.Selanjutnya pengertian kreatif menurut Silberman (dalam Kurniawan, 2012) artinya memiliki daya cipta dan kemampuan berkreasi. 
Agar tercipta generasi yang kreatif dalam arti mampu menghasilkan sesuatu untuk kepentingan dirinya dan orang lain, guru perlu menciptakan kegiatan-kegiatan belajar yang beragam sehingga memenuhi berbagai tingkat kemampuan siswa. Menurut Semiawan (dalam Yunus 2015), daya kreatif tumbuh dalam diri seseorang dan merupakan pengalaman yang paling mendalam dan unik bagi seseorang. Untuk menimbulkan daya kreatif tersebut diperlukan suasana kondusif yang menggambarkan kemungkinan tumbuhnya daya tersebut.

Berdasarkan beberapa pendapat di atas dapat dideskripsikan bahwa menulis kreatif ialah sarana pengungkapan diri melalui tulisan. Menulis bukan sekedar kegiatan motorik tetapi juga melibatkan mental seseorang. Menulis merupakan salah satu media untuk berkomunikasi. Melalui tulisan, seseorang dapat menyampaikan makna, ide, pikiran dan perasaannya melalui rangkaian kata-kata tertulis. Menulis merupakan kemampuan yang dapat dipelajari dan perlu dilatih, karena sebuah keterampilan yang akan semakin terampil bila sering berlatih. Lebih lanjut dapat dideskripsikan pendapat dari beberapa ahli tersebut bahwa kemampuan menulis kreatif adalah kesanggupan atau kekuatan yang dimiliki oleh individu untuk mencipta, berkreasi, mengorganisasikan ide atau pesan secara tertulis sehingga orang lain dapat memahami isinya.

Menulis kreatif pada dasarnya merupakan kegiatan mentransfer ide-ide dan gagasangagasan baru, yang lahir dalam pikiran manusia. Sumardjo (dalam Yunus, 2015) menjelaskan bahwa menulis kreatif adalah suatu proses melahirkan tulisan yang berisi gagasan. Selanjutnya Jabrohim, dkk. (2001) mengemukakan bahwa menulis kreatif sangat terkait dengan potensi bakat seseorang, sehingga menulis kreatif ini cenderung mengarah pada tulisan karya sastra. Beliau mengatakan cenderung pada karya sastra karena menulis kreatif berorientasi pada ide, gagasan-gagasan baru lahir secara terinspirasi dari daya khayal atau imajinatif yang ditulis secara bebas berdasarkan hasratnya.

Dengan demikian, menulis kreatif merupakan suatu upaya mengekspresikan sesuatu yang dilihat, dialami, dirasakan, dan diperkirakan ke dalam bentuk tulisan yang dikemas dalam bentuk seni terutama seni sastra sehingga menghasilkan karya yang baru maupun berlainan dari yang telah ada sehingga dapat dibaca dan dinikmati orang lain.

\subsection{Modal Utama untuk Menulis Kreatif}

Ada tujuh modal utama yang harus dimiliki untuk menulis kreatif menurut Pranoto (2004:10-12), yaitu :

a. penguasaan bahasa dan cara menulisnya,

b. kaya kosakata,

c. memiliki akar dan wawasan,

d. kepekaan terhadap lingkungan,

e. memompa dan mengolah daya imajinasi,

f. konsentrasi,

g. disiplin.

Modal utama menulis kreatif sebagaimana disebutkan di atas menjadi tolak ukur untuk menghasilkan tulisan kreatif yang bermutu sehingga bermanfaat terhadap pembaca.

Adapun manfaat tulisan kreatif kepada setiap orang yang membacanya sebagai berikut:

a. menambah pengetahuan,

b. menambah keterampilan,

c. memecahkan masalah,

d. menghibur,

e. menggugah rasa estetis,

f. menyentuh kepekaan etis (Hadiyanto, 2001:19).

\subsection{Tujuan Menulis}

Seorang tergerak menulis karena memiliki tujuan objektif yang bisa dipertanggungjawabkan dihadapan publik pembacanya. Karena tulisan pada dasarnya adalah sarana untuk menyampaikan pendapat atau gagasan agar dapat dipahami dan diterima orang lain. Tulisan dengan demikian menjadi salah satu sarana berkomunikasi yang cukup efektif dan 
efesien untuk menjangkau khalayak masa yang luas. Atas dasar pemikiran inilah, maka tujuan menulis dapat dirunut dari tujuan-tujuan komunikasi yang cukup mendasar dalam konteks pengembangan peradapan dan kebudayaan mesyarakat itu sendiri. Adapun tujuan penulisan tersebut adalah sebagai berikut. (a) Menginformasikan segala sesuatu, baik itu fakta, data maupun peristiwa termasuk pendapat dan pandangan terhadap fakta, data dan peristiwa agar khalayak pembaca memperoleh pengetahuan dan pemahaman baru tentang berbagai hal yangdapat maupun yang terjadi di muka bumi ini. (b) Membujuk; melalui tulisan seorang penulis mengharapkan pula pembaca dapat menentukan sikap, apakah menyetujui atau mendukung yang dikemukakan. Penulis harus mampu membujuk dan meyakinkan pembaca dengan menggunakan gaya bahasa yang persuasif. Oleh karena itu, fungsi persuasi dari sebuah tulisan akan dapat menghasilkan apabila penulis mampu menyajikan dengan gaya bahasa yang menarik, akrab, bersahabat, dan mudah dicerna. (c) Mendidik adalah salah satu tujuan dari komunikasi melalui tulisan. Melalui membaca hasil tulisan wawasan pengetahuan seseorang akan terus bertambah, kecerdasan terus diasah, yang pada akhirnya akan menentukan perilaku seseorang. Orang-orang yang berpendidikan misalnya, cenderung lebih terbuka dan penuh toleransi, lebih menghargai pendapat orang lain, dan tentu saja cenderung lebih rasional. (d) Menghibur; fungsi dan tujuan menghibur dalam komunikasi, bukan monopoli media massa, radio, televisi, namun media cetak dapat pula berperan dalam menghibur khalayak pembacanya. Tulisan-tulisan atau bacaan-bacaan "ringan" yang kaya dengan anekdot, cerita dan pengalaman lucu bisa pula menjadi bacaan penglipur lara atau untuk melepaskan ketegangan setelah seharian sibuk beraktifitas.

\subsubsection{Puisi}

Secara etimologi, puisi berasal dari bahasa Yunani, poeima "membuat" atau poesis "pembuatan". Dalam bahasa Inggris disebut poem/poetry. Puisi diartikan membuat dan pembuatan karena melalui puisi pada dasarnya seseorang telah menciptakan suatu dunia tersendiri yang berisi pesan/gambaran suasana-suasana tertentu, baik fisik maupun batiniah (Aminuddin, 2004 : 134).

Bentuk kesusastraan yang paling tua adalah puisi. Dalam masyarakat Indonesia, puisi sudah dikenal sejak dahulu. Hampir seluruh kehidupan masyarakat lama tergambar dalam bentuk puisi. Misalnya untuk menggambarkan kegembiraan, kesedihan, cinta, tatakrama dalam kehidupan, dalam pengobatan, dalam kepercayaan dan lain-lain.

Puisi menngeskpresikan pemikiran yang membangkitkan perasaan yang merangsang imajinasi panca indera dalam suasana yang berirama. Puisi itu merupakan rekaman dan interpretasi pengalaman manusia yang penting/berkesan. (Pradopo, 2002:7). Puisi terdiri dari struktur fisik dan struktur batin. Struktur fisik yang membangun sebuah puisi antara lain: diksi, pengimajian, kata konkret, bahasa figuratif, versifikasi, dan tipografi. Struktur batin puisi, antara lain: tema, perasaan penyair, nada atau sikap penyair terhadap pembaca, dan amanat.

\subsubsection{Struktur Fisik Puisi}

Diksi

Pemilihan kata dalam sejak disebut diksi. Penyair hendak mencurahkan perasaan dan isi pikirannya dengan setepat-tepatnya seperti yang dialami batinnya. Selain itu juga ia ingin mengekspresikannya dengan ekspresi yang tepat menjelmakan pengalaman jiwanya tersebut, untuk itu haruslah dipilih kata setepatnya.

\section{Gaya Bahasa} pembaca.

Melalui gaya yang dipergunakannya, penyair menggambarkan daya imajinasi

\section{Rima dan Irama}

Rima adalah bunyi yang berselang/berulang, baik di dalam larik puisi maupun pada akhir larik-larik puisi. Irama yakni paduan bunyi yang menimbulkan unsur musikalitas, baik berupa alunan keras-lunak, tinggi-rendah, panjang-pendek dan kuat-lemah yang 
keseluruhannya mampu menumbuhkan kemerdekaan, kesan suasana serta nuansa makna tertentu.

\section{Tipografi (Tata Wajah)}

Tata wajah atau tipografi berkaitan erat dengan bentuk yang khas dari puisi. Bentuk khas puisi sering kali berperang penting menciptakan makna tambahan yang memiliki kesan tertentu.

\section{Kata Konkret}

Kata konkret adalah kata-kata yang digunakan oleh penyair untuk menggambarkan suatu lulusan keadaan atau suasana batin dengan maksud untuk membangkitkan imajinasi pembaca.

\section{Pengimajian}

Untuk memberi gambaran yang jelas menimbulkan suasana yang khusus, membuat hidup gambaran dalam pikiran dan penginderaan, untuk menarik perhatian, untuk memberikan kesan mental atau bayangan visual penyair menggunakan gambaran-gambaran angan.

\subsubsection{Struktur Batin Puisi}

Menurut Waluyo (1995), struktur batin mencakup tema, perasaan penyair, nada atau sikap penyair terhadap pembaca, dan amanat.

\section{Tema}

Tema adalah persoalan yang ingin diungkap pengarangnya. Setiap seseorang menulis tentu ada yang ingin disampaikannya, yang ingin diungkapkannya.

\section{Perasaan (Feeling)}

Rasa atau feeling merupakan sikap sang penyair terhadap pokok permasalahanpermasalahan yang dikandung dalam puisinya.

\section{Nada dan Suasana}

Nada adalah sikap penyair kepada pembaca. Dalam menulis, penyair bisa jadi bersikap menggurui, menasihati, mengejek, menyindir atau bisa jadi pula ia bersikap lugas, hanya menceritakan sesuatu kepada pembaca.

\section{Amanat}

Amanat atau tujuan adalah hal yang mendorong penyair untuk menciptakan puisinya. Tujuan tersebut dapat berupa kepuasan untuk diri sendiri, tujuan didaktis, tujuan religius, atau kritik terhadap sistem atau individu (dalam Jabrohim, 2001:65)

\section{METODE PENELITIAN}

\subsubsection{Variabel dan Metode Penelitian}

Variabel yang diamati dalam penelitian ini adalah kemampuan siswa menulis kreatif dalam hal ini kemampuan menulis puisi. Metode penelitian yang digunakan dalam penelitian ini adalah metode penelitian yang bersifat deskriptif kuantitatif. Metode deskriptif kuantitatif adalah rancangan penelitian dalam bentuk angka-angka atau statistik. Penelitian ini mendeskripsikan kemampuan siswa menulis kreatif dalam hal ini kemampuan menulis puisi.

\subsubsection{Definisi Operasional Variabel}

Untuk menghindari terjadinya kesalahan dalam menafsirkan variabel yang diteliti, maka peneliti memperjelas definisi operasional variabel yang dimaksud. Kemampuan menulis kreatif puisi adalah kesanggupan atau kecakapan siswa dalam menggubah, membuat, atau menciptakan puisi berdasarkan peristiwa yang pernah dialami dalam bentuk tertulis.

\subsubsection{Populasi dan Sampel}

Populasi adalah keseluruhan subjek penelitian (Arikunto, 2002:108). Populasi dalam penelitian ini adalah seluruh siswa kelas XI SMA Negeri 24 Watampone yang berjumlah 288 siswa terbagi dalam 9 kelas. Sampel dilakukan dengan cara purposive sample atau sampel tujuan. Sampel purposif dilakukan dengan cara mengambil subjek bukan 
berdasarkan atas strata, random, atau daerah tetapi, di dasarkan atas tujuan. Dalam penelitian ini hanya satu kelas yang akan dijadikan sampel yaitu kelas XI E yang berjumlah 32 siswa.

\subsubsection{Teknik Pengumpulan Data}

Teknik pengumpulan data yang digunakan adalah tes tertulis yaitu sampel menulis puisi berkenaan dengan peristiwa yang pernah dialami dengan kata-kata sendiri dengan memperhatikan unsur ekstrinsik dan unsur intrinsik puisi.

\subsubsection{Teknik Analisis Data}

Dalam penelitian ini, data yang terkumpul akan dianalisis dengan menggunakan teknik statistik deskriptif yaitu dengan membuat daftar skor mentah, membuat distribusi frekuensi dari skor mentah, mencari mean (rata-rata), dan mengukur penyebaran.

\subsection{PEMBAHASAN}

Data yang berupa skor mentah dari hasil tes 32 siswa yang dijadikan sampel secara berurutan dari sampel 1 sampai dengan 32. Untuk mengetahui kemampuan menulis kreatif puisi siswa kelas XI SMA Negeri 24 Watampone, terlebih dahulu diuraikan tentang kemampuan menulis kreatif puisi siswa kelas XI SMA Negeri 24 Watampone pada setiap aspek.

Tabel 1.1 Konversi angka ke dalam nilai berkala 1-10 pada aspek tema

\begin{tabular}{|c|c|c|c|}
\hline Skala sigma & Nilai & Skala angka & $\begin{array}{c}\text { Ekuivalensi nilai } \\
\text { mentah }\end{array}$ \\
\hline$+2,25$ & 10 & $9+(2,25 \times 2,25)=14,06$ & $14,0-15,0$ \\
\hline$+1,75$ & 9 & $9+(1,75 \times 2,25)=12,93$ & $12,9-13,9$ \\
\hline$+1,25$ & 8 & $9+(1,25 \times 2,25)=11,81$ & $11,8-12,8$ \\
\hline$+0,75$ & 7 & $9+(0,75 \times 2,25)=10,68$ & $10,7-11,7$ \\
\hline$+0,25$ & 6 & $9+(0,25 \times 2,25)=9,56$ & $9,6-10,6$ \\
\hline$-0,25$ & 5 & $9-(0,25 \times 2,25)=8,43$ & $8,4-9,5$ \\
\hline$-0,75$ & 4 & $9-(0,75 \times 2,25)=7,31$ & $7,3-8,3$ \\
\hline$-1,25$ & 3 & $9-(1,25 \times 2,5)=6,18$ & $6,2-7,2$ \\
\hline$-1,75$ & 2 & $9-(1,75 \times 2,25)=5,06$ & $5,0-6,1$ \\
\hline$-2,25$ & 1 & $9-(2,25 \times 2,25)=3,93$ & $<4,9$ \\
\hline
\end{tabular}

Tabel 1.2 Konversi angka ke dalam nilai berskala 1-10 pada aspek amanat

\begin{tabular}{|c|c|c|c|}
\hline Skala sigma & Nilai & Skala angka & $\begin{array}{c}\text { Ekuivalensi nilai } \\
\text { mentah }\end{array}$ \\
\hline$+2,25$ & 10 & $9+(2,25 \times 2,25)=14,06$ & $14,0-15,0$ \\
\hline$+1,75$ & 9 & $9+(1,75 \times 2,25)=12,93$ & $12,9-13,9$ \\
\hline$+1,25$ & 8 & $9+(1,25 \times 2,25)=11,81$ & $11,8-12,8$ \\
\hline$+0,75$ & 7 & $9+(0,75 \times 2,25)=10,68$ & $10,7-11,7$ \\
\hline$+0,25$ & 6 & $9+(0,25 \times 2,25)=9,56$ & $9,6-10,6$ \\
\hline$-0,25$ & 5 & $9-(0,25 \times 2,25)=8,43$ & $8,4-9,5$ \\
\hline$-0,75$ & 4 & $9-(0,75 \times 2,25)=7,31$ & $7,3-8,3$ \\
\hline$-1,25$ & 3 & $9-(1,25 \times 2,25)=6,18$ & $6,2-7,2$ \\
\hline$-1,75$ & 2 & $9-(1,75 \times 2,25)=5,06$ & $5,0-6,1$ \\
\hline$-2,25$ & 1 & $9-(2,25 \times 2,25)=3,93$ & $<4,9$ \\
\hline
\end{tabular}


Tabel 1.3 Konversi angka ke dalam nilai berskala 1-10 pada aspek nada dan rima

\begin{tabular}{|c|c|c|c|}
\hline Skala sigma & Nilai & Skala angka & $\begin{array}{c}\text { Ekuivalensi nilai } \\
\text { mentah }\end{array}$ \\
\hline$+2,25$ & 10 & $6+(2,25 \times 1,5)=9,37$ & $9,4-10$ \\
\hline$+1,75$ & 9 & $6+(1,75 \times 1,5)=8,62$ & $86,-9,3$ \\
\hline$+1,25$ & 8 & $6+(1,25 \times 1,5)=7,87$ & $7,9-8,5$ \\
\hline$+0,75$ & 7 & $6+(0,75 \times 1,5)=7,12$ & $7,1-7,8$ \\
\hline$+0,25$ & 6 & $6+(0,25 \times 1,5)=6,37$ & $6,4-7,0$ \\
\hline$-0,25$ & 5 & $6-(0,25 \times 1,5)=5,62$ & $5,6-6,3$ \\
\hline$-0,75$ & 4 & $6-(0,75 \times 1,5)=4,87$ & $4,9-5,5$ \\
\hline$-1,25$ & 3 & $6-(1,25 \times 1,5)=4,12$ & $4,0-4,8$ \\
\hline$-1,75$ & 2 & $6-(1,75 \times 1,5)=3,37$ & $3,4-3,9$ \\
\hline$-2,25$ & 1 & $6-(2,25 \times 1,5)=2,62$ & $<3,3$ \\
\hline
\end{tabular}

Tabel 1.4 Konversi angka ke dalam nilai berskala 1-10 pada aspek diksi

\begin{tabular}{|c|c|c|c|}
\hline Skala sigma & Nilai & Skala angka & $\begin{array}{c}\text { Ekuivalensi nilai } \\
\text { mentah }\end{array}$ \\
\hline$+2,25$ & 10 & $9+(2,25 \times 2,25)=14,06$ & $14,0-15,0$ \\
\hline$+1,75$ & 9 & $9+(1,75 \times 2,25)=12,93$ & $12,9-13,9$ \\
\hline$+1,25$ & 8 & $9+(1,25 \times 2,25)=11,81$ & $11,8-12,8$ \\
\hline$+0,75$ & 7 & $9+(0,75 \times 2,25)=10,68$ & $10,7-11,7$ \\
\hline$+0,25$ & 6 & $9+(0,25 \times 2,25)=9,56$ & $9,6-10,6$ \\
\hline$-0,25$ & 5 & $9-(0,25 \times 2,25)=8,43$ & $8,4-9,5$ \\
\hline$-0,75$ & 4 & $9-(0,75 \times 2,25)=7,31$ & $7,3-8,3$ \\
\hline$-1,25$ & 3 & $9-(0,25 \times 2,25)=6,18$ & $6,2-7,2$ \\
\hline$-1,75$ & 2 & $9-(1,75 \times 2,25)=5,06$ & $5,0-6,1$ \\
\hline$-2,25$ & 1 & $9-(2,25 \times 2,25)=3,93$ & $<4,9$ \\
\hline
\end{tabular}

Tabel 1.5 Konversi angka ke dalam nilai berskala 1-10 pada aspek gaya bahasa

\begin{tabular}{|c|c|c|c|}
\hline Skala sigma & Nilai & Skala angka & Ekuivalensi nilai mentah \\
\hline 1 & 2 & 3 & 4 \\
\hline$+2,25$ & 10 & $9+(2,25 \times 2,25)=14,06$ & $14,0-15,0$ \\
\hline$+1,75$ & 9 & $9+(1,75 \times 2,25)=12,93$ & $12,9-13,9$ \\
\hline$+1,25$ & 8 & $9+(1,25 \times 2,25)=11,81$ & $11,8-12,8$ \\
\hline$+0,75$ & 7 & $9+(0,75 \times 2,25)=10,68$ & $10,7-11,7$ \\
\hline$+0,25$ & 6 & $9+(0,25 \times 2,25)=9,56$ & $9,7-10,6$ \\
\hline$-0,25$ & 5 & $9-(0,25 \times 2,25)=8,43$ & $8,4-9,5$ \\
\hline$-0,75$ & 4 & $9-(0,75 \times 2,25)=7,31$ & $7,3-8,3$ \\
\hline$-1,25$ & 3 & $9-(1,25 \times 2,25)=6,18$ & $6,2-7,2$ \\
\hline$-1,75$ & 2 & $9-(1,75 \times 2,25)=5,06$ & $5,0-6,1$ \\
\hline$-2,25$ & 1 & $9-(2,25 \times 2,25)=3,93$ & $<4,9$ \\
\hline
\end{tabular}


Tabel 1.6 Konversi angka ke dalam nilai berskala 1-10 pada aspek kata konkret

\begin{tabular}{|c|c|c|c|}
\hline Skala sigma & Nilai & Skala angka & $\begin{array}{c}\text { Ekuivalensi nilai } \\
\text { mentah }\end{array}$ \\
\hline 1 & 2 & 3 & 4 \\
\hline$+2,25$ & 10 & $6+(2,25 \times 1,5)=9,37$ & $9,4-10$ \\
\hline$+1,75$ & 9 & $6+(1,75 \times 1,5)=8,62$ & $8,6-9,5$ \\
\hline$+1,25$ & 8 & $6+(1,25 \times 1,5)=7,87$ & $7,9-8,5$ \\
\hline$+0,75$ & 7 & $6+(0,75 \times 1,5)=7,12$ & $7,1-7,8$ \\
\hline$+0,25$ & 6 & $6+(0,25 \times 1,5)=6,37$ & $6,4-7,0$ \\
\hline$-0,25$ & 5 & $6-(0,25 \times 1,5)=5,62$ & $5,6-6,3$ \\
\hline$-0,75$ & 4 & $6-(0,75 \times 1,5)=4,87$ & $4,9-5,5$ \\
\hline$-1,25$ & 3 & $6-(1,25 \times 1,5)=4,12$ & $4,0-4,8$ \\
\hline$-1,75$ & 2 & $6-(1,75 \times 1,5)=3,37$ & $3,4-3,9$ \\
\hline$-2,25$ & 1 & $6-(2,25 \times 1,5)=2,62$ & $<3,3$ \\
\hline
\end{tabular}

Tabel 1.7 Konversi angka ke dalam nilai berskala 1-10 pada aspek tifografi

\begin{tabular}{|c|c|c|c|}
\hline Skala sigma & Nilai & Skala angka & $\begin{array}{c}\text { Ekuivalensi nilai } \\
\text { mentah }\end{array}$ \\
\hline$+2,25$ & 10 & $6+(2,25 \times 1,5)=9,37$ & $9,4-10$ \\
\hline$+1,75$ & 9 & $6+(1,75 \times 1,5)=8,62$ & $8,6-9,3$ \\
\hline$+1,25$ & 8 & $6+(1,25 \times 1,5)=7,87$ & $7,9-8,5$ \\
\hline$+0,75$ & 7 & $6+(0,75 \times 1,5)=7,12$ & $7,1-7,8$ \\
\hline$+0,25$ & 6 & $6+(0,25 \times 1,5)=6,37$ & $6,4-7,0$ \\
\hline$-0,25$ & 5 & $6-(0,25 \times 1,5)=5,62$ & $5,6-6,3$ \\
\hline$-0,75$ & 4 & $6-(0,75 \times 1,5)=4,87$ & $4,9-5,5$ \\
\hline$-1,25$ & 3 & $6-(1,25 \times 1,5)=4,12$ & $4,0-4,8$ \\
\hline$-1,75$ & 2 & $6-(1,75 \times 1,5)=3,37$ & $3,4-3,9$ \\
\hline$-2,25$ & 1 & $6-(2,25 \times 1,5)=2,62$ & $<3,3$ \\
\hline
\end{tabular}

Berdasarkan penyajian hasil analisis data, dapat diuraikan tentang kemampuan siswa menulis kreatif puisi. Untuk mengetahui kemampuan siswa, ada beberapa aspek yang menjadi indikator penilaian kemampuan siswa, antara lain: kemampuan menulis kreatif puisi pada aspek tema, amanat, nada, diksi, gaya bahasa, rasa (feeling), kata konkret dan tipografi.

Berdasarkan hasil analisis data kemampuan siswa menulis puisi pada aspek tema diketahui bahwa siswa sampel yang memperoleh nilai 7,0 ke atas berjumlah 12 siswa (37,5\%), sedangkan sampel siswa sampel yang memperoleh nilai di bawah 7,0 berjumlah 20 siswa (62,5\%). Dengan demikian, dapat dikatakan bahwa kemampuan menulis kreatif puisi siswa kelas XI SMA Negeri 24 Watampone pada aspek tema belum memadai. Hal ini dibuktikan dari nilai yang diperoleh siswa sampel yang memperoleh oleh nilai 7,0 ke atas tidak mencapai kriteria tingkat kemampuan siswa sampel, yaitu 85\%.

Pada aspek amanat puisi, dapat diketahui bahwa siswa sampel yang memperoleh nilai 7,0 ke atas berjumlah 3 siswa $(9,38 \%)$, sedangkan siswa sampel yang memperoleh nilai di bawah 7,0 berjumlah 29 siswa $(90,63 \%)$. Dengan demikian, dapat dikatakan bahwa kemampuan menulis kreatif puisi siswa kelas XI SMA Negeri 24 Watampone pada aspek amanat belum memadai. Hal ini dibuktikan dari nilai yang diperoleh siswa sampel yang 
memperoleh nilai 7,0 ke atas tidak mencapai kriteria tingkat kemampuan siswa sampel, yaitu $85 \%$.

Pada aspek nada, diketahui bahwa siswa sampel yang memperoleh nilai 7,0 ke atas berjumlah 18 siswa $(56,25 \%)$, sedangkan siswa sampel yang memperoleh nilai di bawah 7,0 berjumlah 14 siswa (43,75\%). Dengan demikian, dapat dikatakan bahwa kemampuan menulis kreatif puisi siswa kelas XI SMA Negeri 24 Watampone pada aspek nada belum memadai. Hal ini dibuktikan dari nilai yang diperoleh siswa sampel yang memperoleh nilai 7,0 ke atas tidak mencapai kriteria tingkat kemampuan siswa sampel, yaitu $85 \%$.

Pada aspek diksi, diketahui bahwa siswa sampel yang memperoleh nilai 7,0 ke atas berjumlah 3 siswa $(9,38 \%)$, sedangkan siswa sampel yang memperoleh nilai di bawah 7,0 berjumlah 29 siswa (90,63\%). Dengan demikian, dapat dikatakan bahwa kemampuan menulis kreatif puisi siswa kelas XI SMA Negeri 24 Watampone pada aspek diksi belum memadai. Hal ini dibuktikan dari nilai yang diperoleh siswa sampel yang memperoleh nilai 7,0 ke atas tidak mencapai kriteria tingkat kemampuan siswa sampel, yaitu 85\%.

Pada aspek gaya bahasa, dapat diketahui bahwa siswa sampel yang memperoleh nilai 7,0 ke atas berjumlah 11 siswa $(34,38 \%)$, sedangkan siswa sampel yang memperoleh nilai di bawah 7,0 berjumlah 21 siswa $(65,63 \%)$. Dengan demikian, dapat dikatakan bahwa kemampuan menulis kreatif puisi siswa kelas XI SMA Negeri 24 Watampone pada aspek gaya bahasa belum memadai. Hal ini dibuktikan dari nilai yang diperoleh siswa sampel yang memperoleh nilai 7,0 ke atas belum mencapai kriteria tingkat kemampuan siswa sampel, yaitu $85 \%$.

Pada aspek rasa (feeling), dapat diketahui bahwa siswa sampel yang memperoleh nilai 7,0 ke atas berjumlah 16 siswa (50\%), sedangkan siswa yang memperoleh nilai di bawah 7,0 berjumlah 16 siswa (50\%). Dengan demikian, dapat dikatakan bahwa kemampuan menulis kreatif puisi siswa kelas XI SMA Negeri 24 Watampone pada aspek rasa (feeling) belum memadai. Hal ini dibuktikan dari nila yang diperoleh siswa sampel yang memperoleh nilai 7,0 ke atas tidak mencapai kriteria tingkat kemampuan siswa sampel, yaitu $85 \%$.

Pada aspek kata konkret, dapat diketahui bahwa siswa sampel yang memperoleh nilai 7,0 ke atas berjumlah 20 orang $(62,5 \%)$, sedangkan siswa sampel yang memperoleh nilai di bawah 7,0 berjumlah 12 siswa (37,5\%). Dengan demikian, dapat dikatakan bahwa kemampuan menulis kreatif puisi siswa kelas XI SMA Negeri 24 Watampone pada aspek kata konkret belum memadai. Hal ini dibuktikan dari nilai yang diperoleh siswa sampel yang memperoleh 7,0 ke atas tidak mencapai kriteria tingkat kemampuan siswa sampel, yaitu $85 \%$.

Pada aspek tipografi, dapat diketahui bahwa siswa sampel yang memperoleh nilai 7,0 ke atas berjumlah 23 orang $(71,88 \%)$, sedangkan siswa yang memperoleh nilai di bawah 7,0 ke atas berjumlah 9 siswa $(28,13 \%)$. Dengan demikian, dapat dikatakan bahwa kemampuan menulis kreatif puisi siswa kelas XI SMA Negeri 24 Watampone pada aspek kata konkret belum memadai. Hal ini dibuktikan dari nilai yang diperoleh siswa sampel yang memperoleh 7,0 ke atas tidak mencapai kriteria tingkat kemampuan siswa sampel, yaitu $85 \%$. Tingkat persentase kemampuan menulis puisi berdasarkan kedelapan aspek yang dinilai, diketahui bahwa tingkat perolehan persentase yang paling tinggi, yaitu aspek tipografi dengan persentase kemampuan berjumlah 71,88\% di susul oleh aspek kata konkret dengan persentase $62,5 \%$. Selanjutnya aspek nada dengan persentase $56,25 \%$ di susul oleh aspek rasa (feeling) dengan persentase $50 \%$, aspek tema $37,5 \%$ dan gaya bahasa $34,38 \%$ dan aspek amanat dan diksi yang berjumlah sama yaitu 9,38\% .

Rendanya nilai menulis puisi siswa disebabkan oleh beberapa hal, antara lain, siswa rata-rata belum memahami hakikat puisi. Hal ini terlihat dari hasil tes yang dilakukan (puisi siswa). Puisi yang telah dibuat oleh siswa belum mencerminkan sebagai sebuah karya sastra yang memiliki nilai estetik. Selain itu, dari puisi yang dibuat belum tercermin unsur-unsur yang membangun sebuah puisi. Artinya, pemahaman siswa tentang eksistensi unsur-unsur puisi 
masih kurang, seperti siswa belum mampu memahami dengan baik tentang tema, amanat, nada, diksi , gaya bahasa, rasa (feeling), kata konkret dan tipografi.

\section{KESIMPULAN}

Dengan demikian, dapat disimpulkan secara umum bahwa kemampuan siswa menulis kreatif puisi belum memadai. Hal ini disebabkan oleh hasil perolehan persentase nilai dari kedelapan indikator penelitian penulisan puisi, tidak ada satu pun indikator penilaian yang memadai. Dengan kata lain, perolehan siswa tidak ada yang mencapai kriteria keberhasilan dalam menulis puisi.

\section{DAFTAR PUSTAKA}

Aminuddin. 2004. Pengantar Apresiasi Karya Sastra. Bandung: Sinar Baru Algensindo.

Jabrohim, dkk. 2001. Cara Menulis Kreatif. Yogyakarta: Rineka Cipta

Karsana, A. (2002). Keterampilan menulis. Jakarta: Karunika

Kurniawan,Heru dan Sutardi. 2012. Penilaian Sastra Kreatif. Yogyakarta: Graha Ilmu.

Mills, Geoffrey E. 2011. Action Research: A Guide For The Teacher Researcher. Boston: Pearson.

Pradopo, Rachmat Djoko. 2012. Pengkajian Puisi. Yogyakarta: Gadjah Mada University Press.Hadiyanto. 2001. Membudayakan Kebiasaan Menulis (Sebuah Pengantar). Jakarta: PT. Fikahati Aneka.

Pranoto, Naning. 2004. Creative Writing. 72 Juru Seni Mengarang. Jakarta: PT. Prima Media Pustaka.

Suhartini. 2004. "Kemampuan Menulis Puisi Siswa Kelas 3 Bahasa SMAN 1 Bajeng”. Skripsi tidak diterbitkan. Makassar: FBS UNM.

Tarigan, Henry Guntur. 1986. Menulis Sebagai Suatu Keterampilan Berbahasa. Bandung: Angkasa.

Wijacsono, Andri. 2014. Menulis Kreatif Sastra dan Beberapa Model Pembelajarannya. Yogyakarta: Garudhawacana.

Wijayanti, Ervina. 2013. "Peningkatan Kemampuan Menulis Puisi dengan Menggunakan Media Gambar Seri Siswa Kelas VIII SMP Negeri 2 Piyungan Bantul Tahun Ajaran 2011/2012”. Skripsi pada Program Studi Pendidikan Bahasa Sastra Indonesia Universitas Sanata Dharma Yogyakarta.

Yunus, Syarifudin. 2015. Kompetensi Menulis Kreatif. Bogor: Ghalia Indonesia. 